\title{
Studies on wollastonite reinforced recycled polyethene (PE) composites
}

\author{
S. Srikanth ${ }^{1}$, S. Yamuna Devi ${ }^{2}$, Dr R. L Jagadish ${ }^{3}$ \\ ${ }^{1}$ Department of Polymer science Sir M V PG Center, Tubinakere, Mandya. University of Mysore, Mysore. \\ ${ }^{2}$ Department of Polymer science Sir M V PG Center, Tubinakere, Mandya. University of Mysore, Mysore. \\ ${ }^{3}$ Professor, Department of Polymer science Sir M V PG Center, Tubinakere, Mandya. University of Mysore, Mysore.
}

\begin{abstract}
-
Recycling polyethene plays an important role because the consumption of polyethene is more compared to all other plastic materials. Diverting discarded plastics from the refuse stream and turning them into new goods keeps these persistent materials out of landfills and the natural environment to improve the properties of recycled polyethene material, it was reinforced with a good filler[1]. To overcome this and make effective use of recycled polyethene it was reinforced with wollastonite[2]. In this wollastonite was taken in powder form and mixed with recycled polyethene at various proportions, extruded through a twin-screw extruder by the melt mix process. This extrudate can be pelletized and used for making standard specimens as per the international standard Tests. The test result was compared with the base material and there is an improvement in the recycled material after reinforcing with wollastonite filler.
\end{abstract}

Key Words: Recycled polyethene, Wollastonite, composites, injection moulding, Melt mix.

\section{INTRODUCTION}

Plastic goods are useful because they are durable, but this becomes a disadvantage when items are discarded. The natural processes that degrade many paper, cardboard and wood products in a few months don't affect plastic materials as much. In landfills, plastics accumulate, creating a volume of refuse that never seems to go away. In nature, plastic bits and pieces become unsightly nuisances and hazards to animals. Recycling plastic waste plays an important role in the upcoming days. After recycling, the strength of plastic material will decrease due to thermal degradation and reduction in chain length etc. In recent applications almost all plastics are filled with different filler to improve their properties, wollastonite is one type of filler it will improve the mechanical and thermal properties of basic plastic. Wollastonite is a calcium silicate mineral that has high thermal stability. Recycled polyethene with wollastonite filler will improve the strength of recycled plastic strength. For that plastic can be reused especially in plastics like polyethene for different applications it gives the same strength as original polyethene material. Usually, filler improves mechanical properties other additives like heat stabilizers enhance thermal properties and so on. Additives play an important role to enhance the base material property, appearance cost-effectiveness etc. wollastonite is one of the inorganic fillers and minerals also this can be added as an additive with plastics it has very good thermal, mechanical resistance. The waste polyethene plastic was collected and it was reinforced with wollastonite with various proportions.

\section{MATERIALS AND EXPERIMENTS}

Base Material: Injection grade Recycled HDPE material was taken as a polymer base. The study was carried out after adding wollastonite filler into recycled HDPE material.

Filler: Wollastonite (CaSiO3) in the form of powder. The particle size of Wollastonite is 13.83 microns. Which was having $86.50 \%$ brightness compared with $100 \% \mathrm{MgO}$, Bulk density of $0.91 \mathrm{~g} / \mathrm{cc}$ and chemical composition (CaSiO3) as $\mathrm{Cao}+\mathrm{Sio} 292.78 \%$.

Process: Direct mixing techniques in a twin-screw extruder with melt mixing and process using an injection moulding process.

Test Method: Tensile property is one of the mechanical properties. The test method of tensile property is ASTM D 638. Dumbbell shape (Type 1) test specimens were prepared as per the standard ASTM D638. The injection moulding process was used to prepare specimens. As per the standard five samples were tested and the average value has taken.

Study on wollastonite reinforced recycled polyethene (PE) composites: Virgin HDPE material coded as A1 was first tested. Then it was compared with recycled HDPE coded as B1, recycled HDPE+10\% Wollastonite coded as $\mathrm{C} 1$, recycled HDPE+20\% Wollastonite coded as D1, recycled HDPE $+30 \%$ Wollastonite coded as E1, recycled HDPE $+40 \%$ Wollastonite coded as F1. The test result of tensile strength at maximum load for various compositions is mentioned in Table 1 and Graph 1, the Test result of tensile modulus for various compositions mentioned in Table 2 and Graph 2, the Test result of elongation at break is mentioned in Table 3 and Graph 3 .

End Results: It has been observed that wollastonite reinforced recycled polyethene (PE) composites show significantly higher tensile modulus than Recycled 
HDPE and there is a much effect in tensile strength gradual decrease in elongation at break.

Table 1

\begin{tabular}{|c|c|c|c|}
\hline \multicolumn{4}{|c|}{$\begin{array}{l}\text { The test result of tensile properties as per } \\
\text { ASTM D638 }\end{array}$} \\
\hline S.NO & $\begin{array}{c}\text { Sample } \\
\text { description }\end{array}$ & $\begin{array}{c}\text { Sample } \\
\text { Code }\end{array}$ & $\begin{array}{c}\text { Tensile } \\
\text { strength at } \\
\text { maximum } \\
\text { load } \\
\text { Mpa }\end{array}$ \\
\hline 1 & Virgin HDPE & A1 & 24.2 \\
\hline 2 & Recycled HDPE & B1 & 20.7 \\
\hline 3 & $\begin{array}{c}\text { Recycled } \\
\text { HDPE }+10 \% \\
\text { calcium silicate }\end{array}$ & $\mathrm{C} 1$ & 20.7 \\
\hline 4 & $\begin{array}{c}\text { Recycled } \\
\text { HDPE+20\% } \\
\text { calcium silicate }\end{array}$ & D1 & 20.2 \\
\hline 5 & $\begin{array}{c}\text { Recycled } \\
\text { HDPE }+30 \% \\
\text { calcium silicate }\end{array}$ & E1 & 20 \\
\hline 6 & $\begin{array}{c}\text { Recycled } \\
\text { HDPE+40\% } \\
\text { calcium silicate }\end{array}$ & F1 & 18.9 \\
\hline
\end{tabular}

Graph 1

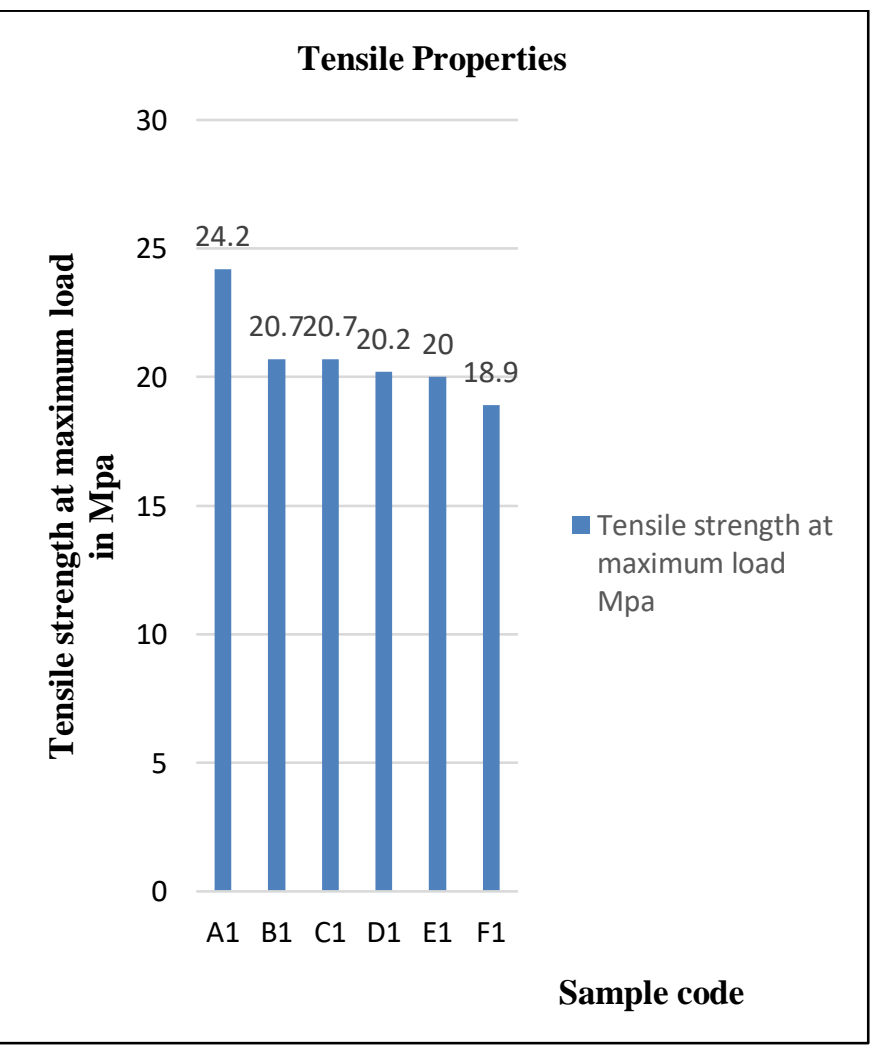

Table 2

\begin{tabular}{|c|c|c|c|}
\hline \multicolumn{4}{|c|}{ The test result of tensile properties as per } \\
ASTM D638 & Tensile \\
\hline & \multicolumn{2}{|c|}{$\begin{array}{c}\text { Sample } \\
\text { Codulus } \\
\text { Mpa }\end{array}$} \\
\hline 1 & Virgin HDPE & A1 & 722 \\
\hline 2 & Recycled HDPE & B1 & 508.1 \\
\hline 3 & $\begin{array}{c}\text { Recycled } \\
\text { HDPE+10\% } \\
\text { calcium silicate }\end{array}$ & C1 & 550.8 \\
\hline 4 & $\begin{array}{c}\text { Recycled } \\
\text { HDPE+20\% } \\
\text { calcium silicate }\end{array}$ & D1 & 730.5 \\
\hline 5 & $\begin{array}{c}\text { Recycled } \\
\text { HDPE+30\% } \\
\text { calcium silicate }\end{array}$ & E1 & 997.4 \\
\hline 6 & $\begin{array}{c}\text { Recycled } \\
\text { HDPE+40\% } \\
\text { calcium silicate }\end{array}$ & F1 & 1200.7 \\
\hline
\end{tabular}

Graph 2

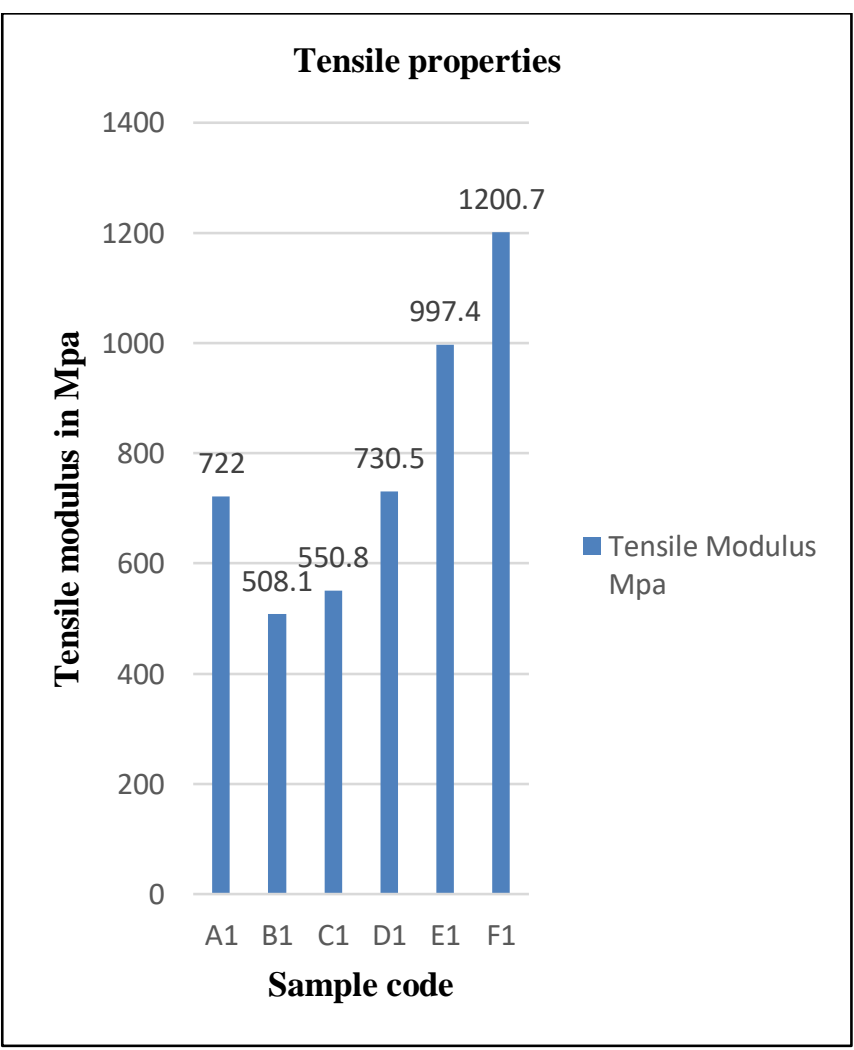


Table 3

\begin{tabular}{|c|c|c|c|}
\hline \multicolumn{4}{|c|}{$\begin{array}{c}\text { The test result of tensile properties as per ASTM } \\
\text { D638 }\end{array}$} \\
\hline S.NO & Sample description & $\begin{array}{c}\text { Sample } \\
\text { Code }\end{array}$ & $\begin{array}{c}\text { Elongation } \\
\text { at break } \\
\%\end{array}$ \\
\hline 1 & Virgin HDPE & $\mathrm{A} 1$ & 201.9 \\
\hline 2 & Recycled HDPE & B1 & 194.7 \\
\hline 3 & $\begin{array}{l}\text { Recycled HDPE+10\% } \\
\text { calcium silicate }\end{array}$ & $\mathrm{C} 1$ & 210.3 \\
\hline 4 & $\begin{array}{c}\text { Recycled HDPE }+20 \% \\
\text { calcium silicate }\end{array}$ & D1 & 28.1 \\
\hline 5 & $\begin{array}{l}\text { Recycled HDPE }+30 \% \\
\text { calcium silicate }\end{array}$ & E1 & 15.1 \\
\hline 6 & $\begin{array}{l}\text { Recycled HDPE+40\% } \\
\text { calcium silicate }\end{array}$ & $\mathrm{F} 1$ & 8.2 \\
\hline
\end{tabular}

Graph 3

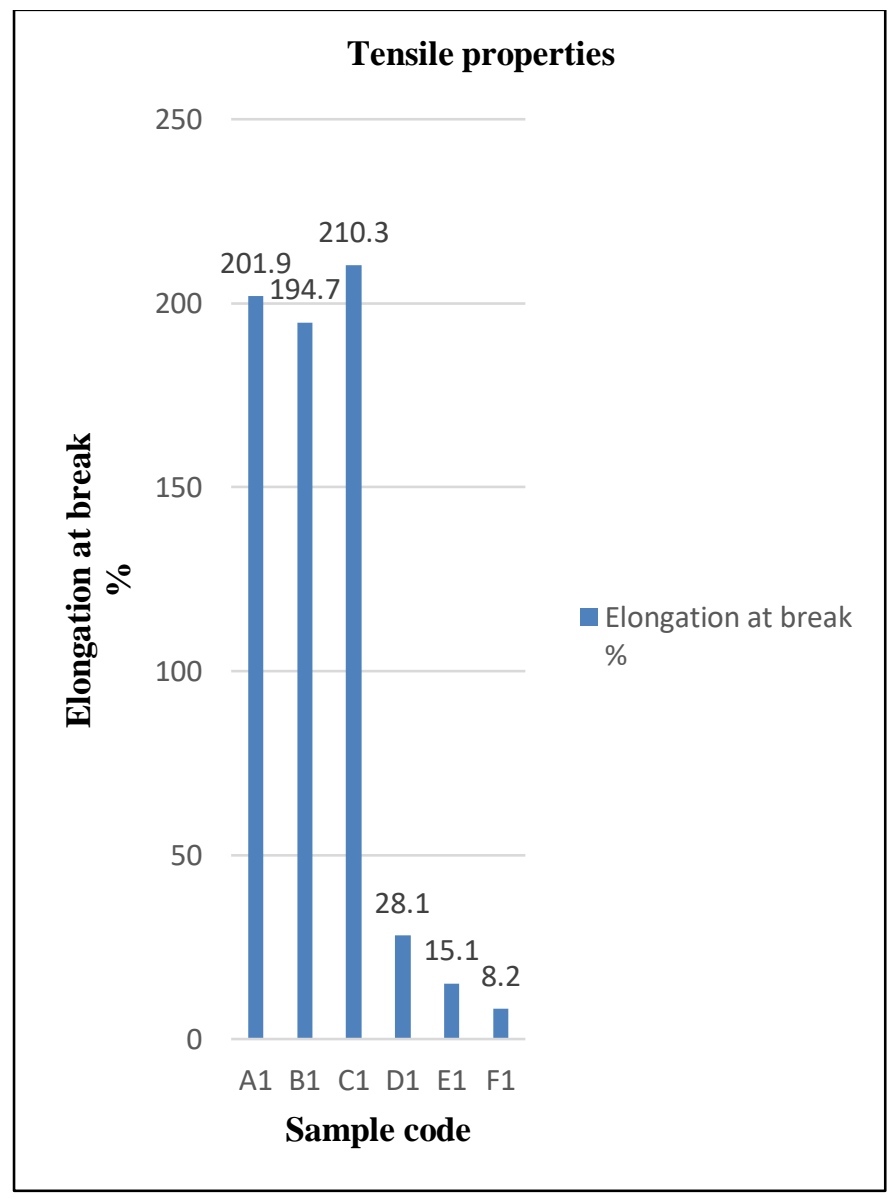

\section{CONCLUSIONS}

The incorporation of filler like Wollastonite to the base recycled Polyethylen improves the tensile modulus and there is no significant change in tensile strength and reduction in elongation at break It can be concluded that wollastonite can be added to polyethene material to achieve stiffness. To make use of recycled PE effectively. Wollastonite reinforced recycled $\mathrm{PE}$ can be used in various applications where original PE can be used.

\section{ACKNOWLEDGEMENT}

The author thanks Dr R. L Jagadish guide for useful advice when writing this article.

\section{REFERENCES}

1. (Plastics, the environment and human health: current consensus and future trends) https://dx.doi.org/10.1098\%2Frstb.2009.0053

2. (Waste management by recycling of polymers with reinforcement of metal powder)http://dx.doi.org/10.1016/j.composites b.2016.08.029 